\title{
Walter Benjamin's Dionysian Adventures on Google Earth
}

\author{
Paul Kingsbury ${ }^{\mathrm{a}, *}$, John Paul Jones III ${ }^{\mathrm{b}}$ \\ a Department of Geography, Simon Fraser University, Burnaby, BC V5A 1S6, Canada \\ ${ }^{\mathrm{b}}$ Department of Geography and Regional Development, University of Arizona, Tucson, AZ 85721, United States
}

\section{A R T I C L E I N F O}

\section{Article history:}

Received 16 October 2007

Received in revised form 4 September 2008

Available online $\mathrm{xxxx}$

\section{Keywords:}

Google Earth

GIS and society

Participatory GIS

Critical cartography

Walter Benjamin

Friedrich Nietzsche

\begin{abstract}
A B S T R A C T
This paper argues, following Friedrich Nietzsche, that recent evaluations of Google Earth uncritically privilege the product's Apollonian determinations at the expense of its Dionysian uncertainties. Specifically, when we understand Google Earth as a virtual globe composed of surveyed panoramas, sober rationalization, dystopic control, and transparent order - or, even, as a tool for participation and empowerment we undersell its capacities as an alluring digital peep-box, an uncertain orb spangled with vertiginous paranoia, frenzied navigation, jubilatory dissolution, and intoxicating giddiness. We argue that the former interpretations not only risk foreclosing our theorizations about how Google Earth is actually used in various ways and different contexts, they also reproduce a one-dimensional and conservative reading of technology that can be traced back (at least) to the writings of Theodor Adorno. By drawing on the work of Walter Benjamin (Adorno's critic and pen pal for more than a decade) we aim to 'go beyond Apollo and Adorno' by illustrating the extent to which Apollonian order and Dionysian love makes Google Earth go round. To do this, we examine Google Earth as a "digital peep-box" with an online collective that revels in its "Spot the Black Helicopter" competitions; illuminated profanities; alien and giant insect invaders; naked sunbathers; and crashed transport planes in Darfur.
\end{abstract}

(c) 2008 Elsevier Ltd. All rights reserved.
"Our taverns and our metropolitan streets, our offices and furnished rooms, our railroad stations and our factories appeared to have us locked up hopelessly. Then came the film and burst this prison-world asunder by the dynamite of the tenth of a second, so that now, in the midst of its far-flung ruins and debris, we calmly and adventurously go traveling." (Benjamin, 1969a, p. 236)

\section{Introduction}

Walter Benjamin's famous essay on art in the age of technological reproducibility - in which he describes how 'the work' loses its aura of originality, authenticity, and ownership - at least foreshadowed, if not ushered in, the collapse of the distinctions between 'high' and 'low', or mass, art. Yet as critics (including Benjamin himself) were to point out, the diminished capacity of the work to demand reverence in the face of widespread reproduction and dissemination is no guarantee of its democratizing potential in the hands of 'the people'. Yes, emancipation from the conservative constraints of history - of ritual, veneration, magic, cult, and exhibition - opens the door to a new cultural politics, but that door can

\footnotetext{
* Corresponding author.

E-mail addresses: kingsbury@sfu.ca (P. Kingsbury), jpjones@email.arizona.edu (J.P. Jones).
}

swing in more than one direction. In Benjamin's time, one portal led to the aestheticization of politics (fascism), the other to the politicization of art (communism). For Benjamin, practices were the battleground for politics, and neither their tendencies nor outcomes (i.e., progressive or otherwise) could be foreclosed in advance: "When the age of mechanical reproduction separated art from its basis in cult, the semblance of its autonomy disappeared forever" (Benjamin, 1969a, p. 226).

Less inclined to see any positive values in popular culture was Benjamin's friend and fellow Frankfurt School theorist, Theodor W. Adorno. Concerned about the distractive potential of mass art, Adorno believed that only the negative and dissonant 'authentic art' of the avant-garde provided a refuge for individuality and resistance to the culture industry (Kellner, 1989). Thus, even though in his writings one might find "residues of a utopian insistence on radical change," in the dialectic between despair and hope that was a hallmark of the Frankfurt School, the latter for Adorno "was by far the weaker and more muted of the two" (Jay, 1984, p. 242).

Both Benjamin and Adorno brought these critical stances to bear on the cultural medium of film in the mid-twentieth century. For Adorno, film was no more let off the hook of ideology critique than the other forms of entertainment promulgated by the culture industries, such as radio and television. From the 1940s classic, Dialectic of Enlightenment (1991), which Adorno co-authored with Max Horkheimer and in which the term 'culture industry' first 
makes an appearance, to his 1967 'reconsideration' of entertainment (Adorno, 1989), he was to look upon film with disdain, a form of mass standardization, "uniform as a whole and in every part" (Horkheimer and Adorno, 1991, p. 120), designed solely to turn spectators into consumers. Extending Benjamin's insights regarding mechanical reproduction into a profound distrust of the visual immediacy of film, Adorno separated the culture 'industry' from 'art' insofar as the former always remained external to its object: "Each product affects an individual air; individuality itself serves to reinforce ideology, insofar as the illusion is conjured up that the completely reified and mediated is a sanctuary..." (Adorno, 1989, p. 130). As an intensely visual, spatial representation, Adorno held that color film "demolishes the genial old tavern to a greater extent than bombs ever could.... No homeland can survive being processed by the films which celebrate it, and which thereby turn the unique character on which it thrives into an interchangeable sameness" (1989, p. 132).

If there was a redemptive moment in Adorno's version of film, it came late in life and was grounded in a modest rethinking of both filmic technique and subject positionality (see Hansen, 1981/82 on Adorno, 1981/82). First, he came to see the potential of montage and other cinematic shock effects (also see Doel and Clarke, 2007) to disrupt the comfort of normal viewing that, he once reported, made him stupid; second, there was creeping recognition that cinematic viewership might be multidimensional enough to warrant empirical studies of reception from the field of communication (Adorno, 1981/82). Regardless of how much he might have moved toward Benjamin's notion of adventuresome traveling through film, a position that assures us "of an immense and unexpected field of action" (Benjamin, 1969a, p. 236), it is clear that Adorno and Benjamin set the parameters of a dialectic of cultural criticism - dreary versus utopian, fear versus hope - that continues to this day (see also Philo, 2006).

Of primary interest to us here is the fact that the parameters within which Benjamin and Adorno worked not only apply to film, but likewise to critical discussions of cartography, GIS, and other geospatial technologies (GSTs). At one end are fearful, dystopic accounts of GSTs in the service of panoptic control. As Klinkenberg (2007, p. 350) explains in a recent article:

"Geospatial technologies appear entrenched in surveillance, warfare, and invasion of privacy, and human geographers have been quick to address these roles. They point to an Orwellian future that appears to be running amok, where smart cards invade our privacy and satellite surveillance becomes public fare. GSTs represent a tidal wave of change in our societal structure, and appear to be leading us toward the brink of a "brave new world."”

This sort of 'surveillant society' critique seems especially apt in a post-9/11 world where closed-circuit televisions (CCTVs) monitor spaces at the street level while satellite technologies do the same from the sky. Yet at the other end one does not have to look too far to find a more hopeful tone that focuses on the alternative uses to which GSTs can be put. As Klinkenberg argues, critical social theorists need to engage rather than simply repudiate GSTs. He then points to several recent developments along those lines, including a more socially responsible and involved approach on the part of advocates of GIS that opens up a previously perceived "single official reading" (2007, p. 351, quoting Hoeschele, 2000, p. 296), as well as to the increasing democratization of GSTs in the form of participatory approaches that place technology in the hands of the many instead of the few (Elwood, 2006; Goodchild, 2007).

These seemingly opposed yet still critical stances toward GSTs can be found throughout geography, whether under the name of
GIS and society (GISoc), critical cartography, critical GIS, public participation GIS (PPGIS), or participatory GIS (PGIS) (O'Sullivan, 2006; Sieber, 2006). For it is in this literature that one finds the structural moments that underpin critiques of technology: where the military-industrial complex is positioned against well-meaning, progressive social theorists of technology and their diverse, now GIS-equipped publics aiming to expose, through mapping and spatial analysis, legacies of local socio-environmental degradation. Our aim in this paper is to complicate this fear-hope dialectic in critical studies of geospatial technology. Our purpose is not to deride this oppositional formation, and indeed our own perspective is derived from it and therefore is marked by this same binary. Rather, we hope to uncover an alternative view through Benjamin, one suggested by his open-ended, practice-based approach to epistemological and political shifts accompanying the rise of a new, ground-breaking technology.

In order to develop this potential, we align Benjamin's emphasis on the indeterminacy of technology with Friedrich Nietzsche's reading of Greek tragedy, wherein the rigid criticality of Apollonian determinations - either surveillance or resistance - is counterpoised to the un-tethered openness of Dionysian uncertainty. In short, we read both dread and hope as a dialectical pairing within a precoded Apollonian worldview, while posing in a Dionysian alternative a minor political theory (Katz, 1996) that is never foreclosed but is, rather, vigilant to the immanence of technology-in-use (also see Kitchin and Dodge, 2007). Our focus is on a relatively new but widely popular GST: Google Earth. Here we respond directly to recent works that have already and will doubtless continue to read Google Earth as an Apollonian entity composed of control, order, and calculation, as well as to those who have celebrated its utility in democratizing mapping practices. Again, it is not so much that these choices are 'wrong', but that they are limiting, two parts of a sobering, recursive yin and yang that elides the extent to which Google Earth is also a Dionysian entity, that is, the projection of an uncertain orb spangled with vertiginous paranoia, frenzied navigation, jubilatory dissolution, and intoxicating giddiness. We argue that Apollonian interpretations (to resist or play ball), when unleashed on Google Earth, will not only risk truncating our theorizations about how it is actually used in various ways and different contexts, but will reproduce a one-dimensional, softcore politics and conservative reading of technology that can be traced back (at least) to the writings of the Frankfurt School. By integrating Dionysus with Benjamin, Adorno's pen pal for more than a decade (Benjamin and Adorno, 2003), we aim to 'go beyond Apollo and Adorno'.

\section{Apollonian determinations}

"[t]he Nietzschean distinction between Apollonian and Dionysian echoes the dual aspect of the living being and its relationship to space - its own space and the other's: violence and stability, excess and equilibrium." (Lefebvre, 1991, p. 178)

As Lefebvre anticipated in the mid-1970s, when The Production of Space was written, Nietzsche's aesthetic theory is applicable to Google Earth for at least two reasons: first, because it permits an integration of social experience and space; and second, because it does not rely on the fixity of either the subjects or objects of aesthetic reflection (see also Wainwright, 2009). Exemplary of Nietzsche's theory is The Birth of Tragedy (originally published in 1872), a trenchant critique of Enlightenment aesthetics. In this early and enormously influential text, we find Nietzsche's (1999, p. 33; emphasis in original) celebrated declaration: "for only as 
an aesthetic phenomenon is existence and the world eternally justified". The 'birth of tragedy' is the initial moment of decline of the artistic value of Greek tragedies.

Nietzsche singled out Socrates, who reformed Greek aesthetics by asserting that the beautiful had to be made intelligible and understood through the virtues of knowledge. Nietzsche asserts that Socrates is too logical, scientistic, and serious. Under the influence of Socratic philosophy, Greek playwrights aspired to achieve logical unity rather than the dramatic effect produced by the transformative impact of audience participation. In The Birth of Tragedy, Nietzsche aims to reaffirm the turbulent, subjective, and sensual elements of aesthetic experience alongside elements of unity and intelligibility. For Nietzsche, the fusion of Apollonian restraint and Dionysian abandonment were essential to the aesthetic greatness of pre-Socratic Greek tragedies. Furthermore, Nietzsche argues that to live a truly meaningful life, one must aspire to combine both Apollonian and Dionysian principles.

What are the Apollonian and Dionysian? They are the broad, mutually affirmative categories that Nietzsche (1999, p. 19; emphasis in original) defines as "artistic powers which erupt from nature itself, without the mediation of any human artist." The Apollonian principle for Nietzsche, associated with the Greek deity Apollo, is chiefly concerned with dreams, serenity, ordered boundaries, self-conscious contemplation, and the plastic art of sculpture. For Nietzsche (1999, p. 16), Apollo is: "the god of all image-making energies, Apollo is also the god of prophecy. According to the etymological root of his name, he is 'the luminous one' (der Scheinende), the god of light; as such he also governs the lovely semblance produced by the inner world of fantasy."

Exemplifying the Apollonian view of Google Earth is a recent paper by Chad Harris. Titled "The Omniscient Eye: Satellite Imagery, 'Battlespace Awareness', and the Structures of the Imperial Gaze", Harris (2006, p. 102) writes that:

“Google Earth ${ }^{\mathrm{TM}}$... [produces] objectivity, a techno-discursive distance between the observer and the observed, and a particular kind of modern surveillant subject. This subjectivity is structured by an omniscient, imperial gaze, a particular kind of subjectivity that signifies dominance over what is being observed."

Such a view resonates throughout much of critical cartography and GIS in suggesting a one-to-one mapping of technology onto epistemology. Harris goes on to specify this relationship:

"The perspective is one of a totalizing, objectifying transcendent gaze, and allows one to transcend the subjective world - what Donna Haraway calls the "God Trick" (Haraway, 1988), or what Denis Cosgrove has called the "Apollonian Eye" (Cosgrove, 2001) - that has been an essential ideological component of global control and conquest since antiquity. Its power as knowledge is derived from its position above and beyond subjectivity, and as Cosgrove asserts, it is "implicitly Imperial..." (p. 119)

In the face of such a tight knot of power/knowledge, where mapping is not simply inherently political, but political in a particular direction (global control and conquest), it is little wonder that our choices are either to launch a broadsided and univocal critique against techno-power or, in an attempt to appropriate that power, to 'take back the maps'. ${ }^{1}$ Readers of the Frankfurt School will be reminded here of how much this view resonates with Adorno's stance with respect to technology: cynical, conservative, and even nervous (see Adorno, 1990). And to be sure, Adorno held a deep-seated dis-

${ }^{1}$ For an exemplary caution to similar injunctions underlain by the 'romance of resistance', see Sparke (2008). trust or fear of mobility: "More haste, less speed", he once wrote of modern travel (Adorno, 2005, p. 102, emphasis in original).

\section{Dionysian intoxications}

"Our taverns and our metropolitan streets, our offices and furnished rooms, our railroad stations and our factories appeared to have us locked up hopelessly. Then came Google Earth and burst this prison-world asunder by the dynamite of 100 megabits per second, so that now, in the midst of its far-flung ruins and debris, we calmly and adventurously go traveling."

Attentive above all to the epistemological shakeups of technology, Benjamin (1969a, p. 236) went on to amplify this quote - modified here from its original by substituting Google Earth for film - by suggesting that: "With the close-up, space expands; with slow motion, movement is extended." Commenting on the ways in which the "camera introduces us to unconscious optics as does psychoanalysis to unconscious impulses," Benjamin (1969a, p. 237) gives a different critical stance to the possibilities and uncertainties that reside in the machinic assemblage of Google Earth. At the same time: Benjamin's constant peregrinations; his unusual style of writing, which Susan Sontag (2002, p. 129) referred to as "freeze-frame baroque"; his uncoding of the 16th and 17th century German genre of plays (see also Buci-Glucksmann, 1994), Trauerspielen, which were said to unfold only in space (i.e., in the absence of time); his experimentation with hallucinogens (hashish, mescaline, and opium); and his obsession with the dazzling spatializations of modernity in the arcades of Paris, make him a fitting figure for an analysis of the Dionysian moments we might find in Google Earth. In brief, it is this principle, associated with the wine god Dionysus, which aligns itself with excess, disorder, sensuous ecstasies, fertility, and the non-plastic art of music. Nietzsche writes that the Dionysiac is:

"best conveyed by the analogy of intoxication. These Dionysiac stirrings, which, as they grow in intensity, cause subjectivity to vanish to the point of complete self-forgetting. . Singing and dancing, man [sic] expresses his sense of belonging to a higher community; he has forgotten how to walk and talk and is on the brink of flying and dancing, up and away into the air above." (1999, p. 17-18; emphasis in original)

According to Wolin (2006, p. 3), "Benjamin's drug experiences show once again how singularly committed he was to the program of the avant-garde: overcoming the limitations of the self by subjecting it to an array of pulverizing, Dionysian, ego-transcending influences." Benjamin's work is full of scrolling, vertiginous descriptions of heterogeneous spaces, an example of which can be found in the essay, "Naples", which he co-authored with his Latvian Bolshevik lover, Asja Lacis (Benjamin and Lacis, 1978). Parts of the essay focus on the intermingling of public and private space - what Benjamin called the 'porosity of space' - a concept allegorically repeated in Google Earth's invitation to users to enter gated communities, prohibited sites such as Area 51 (a.k.a "Dreamland"), and the border along the two Koreas. ${ }^{2}$ As in the streets of Naples, Google Earth provides ample opportunities for improvisation and unplanned movement.

Indeed, Benjamin's much studied Parisian flâneur invites numerous parallels to the Google Earth user as an anonymous wandering detective, an active spectator whose meanders over the landscape are guided in parts by the former's 'distracted attentions' (Lucas 2004) and in other parts by the latter's web-produced 


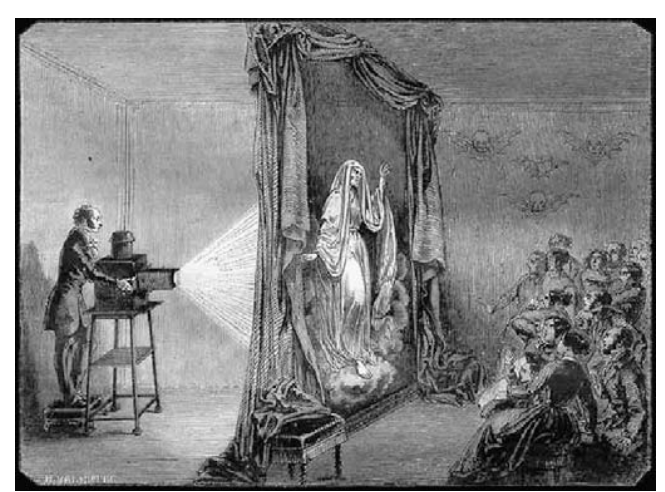

Fig. 1. Robertson's phantasmagoria machine.

'attentive distractions'. Both subjects have been enabled by architectonic and techno-scientific shifts: in one case from the vehicle-dense, pedestrian-unfriendly streets of Paris to the intensely peopled, ambulatory experience of the arcades (Lucas, 2004); in the other case from the static folds and turns of paper maps and atlases to the mobile, twinkling screens. And both flâneur and Googler Earthling stroll (or scroll) through space: "Landscape - that, in fact, is what Paris becomes for the flâneur. Or, more precisely: the city splits for him [sic] into its dialectical poles. It opens up to him as a landscape, even as it closes around him as a room" (Benjamin, 1999, p. 417).

Of course it is doubtful that a Dionysian Google Earth will accomplish what Benjamin set out to do: "win the energies of intoxication for the revolution." But surely it offers possibilities for new readings of techno-culture that are far from the dystopic options of Apollonian control. For example, Benjamin was obsessed with places and objects, and his experiments with drugs may have led to the conclusion that distanced objects - rather than being objectified - were able, in his words, to "return our gaze" (cf. Rose, 1993). That these might be the grounds for an intoxicating experience can be at least proposed through Benjamin's study of the phantasmagoria machine, a late 18th and early 19th century contraption that was popular in the theatres of Paris and London (Fig. 1). The machine was a projector with candle illumination and concave and convex lenses to focus light and project images, which would be painted on small glass slides. The operator stood behind a gauze screen suspended in front of an audience, on to which would be projected ghostly images whose spectral force would be intensified by moving the screen and by supplementary audio supplied by assistants (Castle, 1988). The phantasmagoric parallel to Google Earth was provided by an invention of Etienne Gaspard Robertson (1763-1837), a Belgian optician and showman who made a remarkable career scaring European audiences witless. He devised a tracking system that enabled him to increase and decrease the projected apparitions, and the looming and zooming figures were said to have shaken the audiences out of their seats, some of them running toward rather than away from the projections. ${ }^{3}$

\section{Surfing under the influence of Google Earth}

"For a business entity user, the Software may be used by you and your employees for internal use according to these

\footnotetext{
${ }^{3}$ Thanks to a reviewer for pointing out an additional technological-epistemological parallel, one well suited to historicizing Google Earth: Patrick Geddes's 'Outlook Tower' (see Matless, 1992).
}

Terms of Service and the Software documentation (individual end users and business end users are collectively referred to as 'You' herein)." (Google Earth Download “Terms of Service")

"The Apollonian rules we pass to govern the workplace will never fully control the demonic impulses of Dionysian night." (Paglia, 1994, p. xi)

In this section we draw on the dynamic duo of Apollo and Dionysus to explore Google Earth's alluring and oftentimes bizarre images, seductive interface, incitement of feverous online discussions, and intertwining of the political and the poetic. ${ }^{4}$ To do this, we focus on the following: first, the claim that Google Earth is a collectively used 'digital peep-box'; second, the idea that Google Earth's grip on users lies not so much in its ability but rather its failure to clearly reveal a visible and legible world; and third, by considering Google Earth as exemplary of what Gearóid Ó Tuathail (1996) calls an 'anti-geopolitical eye', we argue Google Earth challenges our usual (that is, Foucauldian) understandings of panoptic power. Finally, we discuss the ways in which Google Earth can be understood as an enigmatic and aesthetic artifact that prompts us to consider a "significant disjunction between the politics and ethics of cultural study” (Dean, 2002, p. 31).

\subsection{The digital peep-box and GeoCom}

Acknowledging the enduring influence of Waldo Tobler's late1950s MIMO (map in/map out) system that converted maps for computer use, Lammeren and Bergsma (2006) argue that Google Earth is at the forefront of the shift in Web services from specialized digital-map toolboxes to everyday geo-virtual realities (see also Hedley, 2009). Lammeren and Bergsma (2006, 31) liken Google Earth to a 'digital peep-box':

"As children many of us rose to the challenge of transforming a shoebox into a peep-box. We decorated the faces inside with pictures cut out of glossy magazines or painted them, glued cardboard objects onto the floor of the shoebox and hung them from the ceiling on bits of string. The faces formed boundaries and the light coming through one or more holes, often covered with coloured cellophane to create a mysterious atmosphere, illuminated the scene. Looking through the peephole gave the feeling of being in an imaginary world."

For Lammeren and Bergsma, the peep-box boundary equates to Google Earth's 3D geo-referenced scene, the peep-box faces stand in for Google Earth's digital pictures and bit-maps, the cellophane represents Google Earth's 'atmospheric lights' and 'clear blue skies', while the peephole mimics the interface between users and the 3D scene.

For us, the metaphor of a digital-peep box is particularly apt for two reasons: first, because the notion of 'peeping' echoes not only the Apollonian act of looking and spying but also the Dionysian joy and giddiness that easily turns the charm of looking into the erotics of ogling. Second, Lammeren and Bergsma's evocation of a childhood practice recalls Benjamin's Nietzschean affirmation of the magic and wisdom of childhood, that is, delighting in the world's minutiae, playfulness, and disorientation (see Adorno, 1967, p. 227-241). Like the peep-box and the phantasmagoria machine studied by Benjamin, Google Earth invites an intoxicating array of responses to its zooming, tilting, and rotating imagery. While users can navigate with an Apollonian eye on Google Earth's features such as its 'Pointer' to coordinate latitude and longitude, its

\footnotetext{
${ }^{4}$ We agree with Matthew Sparke's suggestion that there could be other Gods and Goddesses that make Google Earth go around (see also Lykke and Braidotti, 1996).
} 
'Eye Alt' to check altitude, and the 'Fly To' and 'Search Panel' in order to specify destinations, they can also indulge in the thrill of unchecked aleatory journeys. Thus, Benjamin might ask, what does it mean to get lost with Google Earth, and with what value?

The answer might be found in Benjamin's writing about his youth in Berlin Childhood around 1890. In it he was to poignantly observe: "Not to find one's way around in a city does not mean much. But to lose one's way around a city, as one loses one's way in a forest, requires some schooling" (quoted in Wolin, 2006, p. 3). ${ }^{5}$ The schooling of getting lost in Google Earth's "interfacing, data fusion, data representation, simulation and feedback" (Lammeren and Bergsma, 2006, p. 32) is configured by the Dionysian "oceanic feeling" (Freud, 1961, p. 11) of online oneness that floods the discussions about Google Earth in numerous forums and blogs. To be sure, relishing en masse in the comely and often quirky satellite imagery of the earth is not new. For example, in Turnbull and Turnbull's (2006) Off the Map: The Most Amazing Sights of Earth as Seen by Satellite, we witness "Plug Holes in the Mediterranean; Arizona's Boneyard; The White Snake of Baja; The Hole in the Coast of Mexico; Face of Jesus Found in the Sand Dune, Area 51". But for Lammeren and Bergsma, what makes Google Earth different to photographs in a book or online images is its "dynamic, multi-response" digital peep-box character, based on "distributed computing and interoperability... interaction, simulation, feedback and scene sharing", all part of "Geodata based Communities" ('GeoCom'). In addition to features such as photographs of landmarks and landscapes submitted by photographers and the informational pop-up links to websites such as Wikipedia, Google Earth's further integration into the Web includes blogs such as Google Earth Hacks, Google Sightseeing, Google Earth Blog, Juicy Geography, and Ogle Earth. Google Earth, then, arguably not only incites as much discussion as it does exploration, it also blurs and collapses the very distinction between the two (see also Zook and Graham, 2007). Notably, the official Google Earth Community web forum over one million registered users, often with more than a thousand users online at any given time. ${ }^{6}$ In concluding their account of Google Earth, Lammeren and Bergsma (2006, p. 33, emphasis added) write:

"Since GeoCom will gradually be integrated into society, there really is a need for awareness, understanding and keeping up with the developments involved. Whereas GIS education was originally embedded in other Earth Sciences, today GIS education programmes are on the curricula of all schools, from primary to higher-education institutions. So perhaps it is not at all surprising that our interest in geo-information begins with constructing a (digital) peep-box!"

Apollo and Dionysus enable us to keep up with Google Earth's fast-paced developments by enhancing our understandings of the 'digital peep-box' and GeoCom dimensions of Google Earth. Before turning to our analyzes of these elements, we recommend that online readers of this article download and activate Google Earth in order to navigate the referenced Keyhole Markup Language links (or KMZ files), so as to fully appreciate the extent to which Apollo and Dionysus make Google Earth go round.

\subsection{High-dissolution}

Denis Cosgrove's writings on the Apollo 17 photographs of Earth from space (Cosgrove, 1994) and “Apollo's Eye” qua the

\footnotetext{
${ }^{5}$ Benjamin's observation is also applicable to Google Maps' "Street View" program which allows users to "explore neighborhoods at street level-virtually" and "tour streetscapes and see $360^{\circ}$ images". We believe Street View is also an amalgamation of Apollonian and Dionysian elements.

${ }^{6}$ See http://bbs.keyhole.com/ubb/ubbthreads.php/Cat/0.
}

"cartographic genealogy of the Earth in the Western imagination" (Cosgrove, 2001), though engaged with the mildly Dionysian elements of intertextuality, sublimity, contestation, and shifting historicity, rarely dispute the idea that (Western) visions of the world could be something other than Apollonian: dreamy yet transcendental, partial yet universalizing and omniscient, contextual yet controlling and ordering. For Dionysus is certainly subdued and tucked away on the wagon in Cosgrove's frequently beautiful yet occasionally blanched or hard-boiled ordering of things visible.

A less-watchful eye on vision could begin with Benjamin's (2006, p. 132-133) notion of a 'profane illumination': “a materialistic, anthropological inspiration, to which hashish, opium, or whatever else can give an introductory lesson." For Benjamin, profane illumination, a strategy he aligned with the Surrealist movement (see Benjamin, 1978), takes place when suddenly, as a result of dreaming, narcotics, love, solitude, or simply thinking, an everyday object is elevated to the status of something disturbingly strange and intoxicatingly uncanny. If computing is still "the new LSD" (Leary, 1994) and Google Earth part of the "computational sublime", then it is hardly surprising that much of the online discussion of Google Earth involves profane illuminations qua cyberdelic "consensual hallucinations". 7 Two examples from website The Register (a key source for our paper $^{8}$ ) should suffice. First, is the report of "Germany menaced by $50 \mathrm{~m}$ insect" (Fig. 2) ${ }^{9}$ Lester Haines notes:

\section{"Sharp-eyed Google Earth monitors have this morning alerted Vulture Central to the threat posed to humanity by a giant earwig which is as we speak rampaging its way across the German countryside. . Make no mistake, this is the mother of all earwigs, advancing southwestwards towards the sleepy hamlet of Arlesberg."}

Our second example is from a Google Earthling who spotted the attempted invasion of earth by aliens, specifically Kaled mutants, called Daleks - the arch enemy of the BBC's fictional time-traveler Doctor Who (see Fig. 3). The Daleks were "poised to exploit this rift in the space/time continuum" - in Holland. ${ }^{10}$ The Register reports that Dutch Google Earth users "particularly those living in Hilversum...should immediately arm themselves with pulse plasma rifles and prepare to defend their homeland from interdimensional attack". At the time of writing, unlike the giant insect, the rift was still visible on Google Earth and pinpointed by one user as an "interdimensional portal". ${ }^{11}$

Perhaps less other-worldly yet equally vertiginous are the numerous illuminated profanities on Google Earth. The Register includes hi-res Google Earth profanity that "beats crop circles for crowd-pleasing entertainment" (Fig. 4). ${ }^{12}$ These images include a "a cryptic message for humanity in a corn field" or the 40 meter-high words of "Eddie" and "Fuck"; the word "Poo!" etched in a wheat field to the north of Edinburgh; and a farmer "who has decided to greet extraterrestrial visitors to our beautiful planet in the time-honoured local fashion" by etching the word 'arse' in a wheat field "somewhere

\footnotetext{
7 See http://www.metamute.org/en/Consensual-Hallucinations-or-The-Birth-ofthe-Computational-Sublime. The notion that computing is the new LSD appears less spurious when one considers the massive growth in the Dionysian intoxications of the "Massively Multi-User Augmented Realities" such as "Second Life" and "Red Light Center".

${ }^{8}$ Founded in 2000 , The Register is a UK and US-based website that publishes weekly news, RSS feeds, and opinion pieces on technology, music and media, internet security, and data management. Renowned for its satire and sarcasm, The Register receives more than four million visitors a month.

${ }^{9}$ See http://www.theregister.co.uk/2006/09/28/giant_insect/.

10 See http://www.theregister.co.uk/2006/09/18/interdimensional_portal/.

11 Line of flight: http://regmedia.co.uk/2006/09/18/interdimensional_portal.kmz.

12 See http://www.theregister.co.uk/2006/02/10/giant-profanity/.
} 


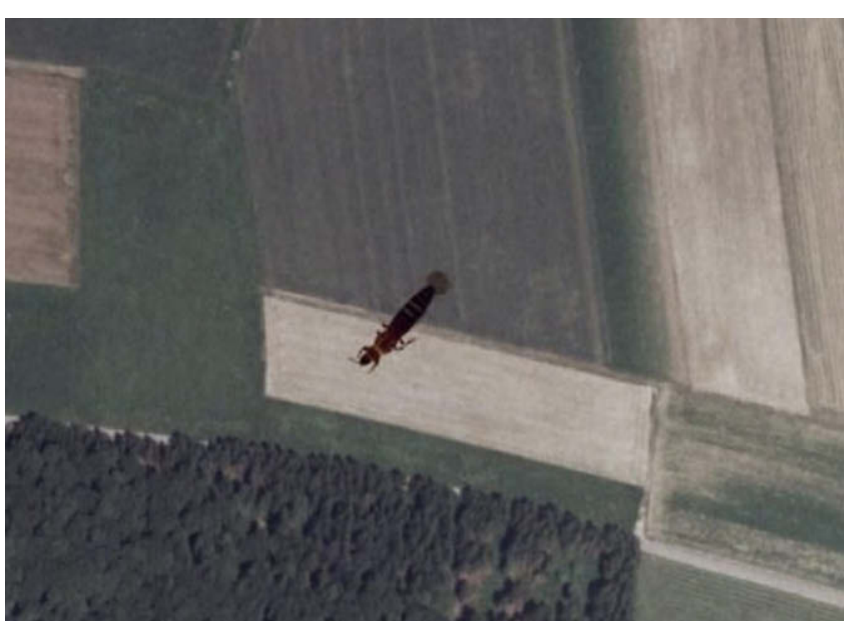

Fig. 2. 50 meter long insect near Hülen, Baden-Württemberg, Germany. (Source: http://www.panoramio.com/user/66070.) (Line of flight: http://regmedia.co.uk/ 2006/09/28/giant_earwig.kmz).

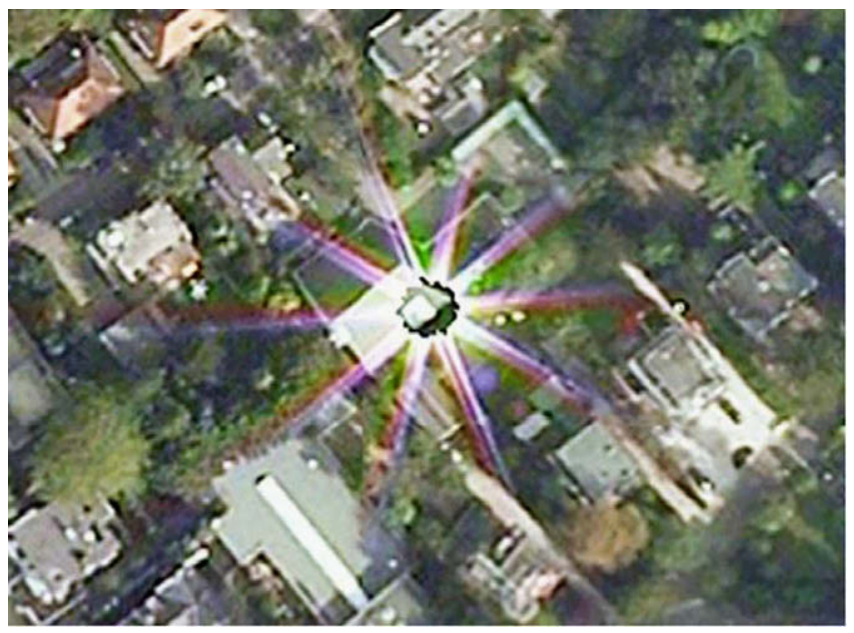

Fig. 3. Rift in the Google Earth space/time continuum. (Source: http://www.theregister.co.uk/2006/09/18/interdimensional_portal/).

south of Rotherham and east of Sheffield". ${ }^{13}$ An even more alluring voyeuristic romp can be found on the website Google Sightseeing, which touts the 'Top 10 Naked People on Google Earth'. ${ }^{14}$ Here, Google Earth users submit images of people in various states of undress. The captions for persons number five and six read as follows:

"Outside a café on the beach (presumably before it opened that day), we find someone sitting calmly in a chair, blissfully unaware the whole world can now see them in their birthday suit."

"The previous nudist may have also been unaware that just on the other side of the building, there was another person sunning themselves - flat on their back and completely in the altogether! Does anyone know someone that works in this café by the way?"

The Dionysian excitement of perusing naked people on Google Earth involves not so much reveling in the sight of flesh revealed, but rather the confusion and ensuing intense discussions about the naked people's age, gender, and the extent of their nakedness.

\footnotetext{
${ }_{13}$ See http://www.theregister.co.uk/2006/05/31/huge_word/.

14 See http://googlesightseeing.com/2006/11/28/top-10-naked-people-on-googleearth/.
}

As the user "cookie monster" reminds us, "[t]he internet is over flowing with naked people doing naughty things to each other and yet we still get all excited by some tiny people about 10 pixels high (and they are not even naked most of the time)". Thus Google Earth's allure derives not only from its capacity for high-resolution (Caplan, 2006) but also from high-dissolution, or what Camille Paglia (1991, p. 98) calls the "wet dream of Dionysian liquidity [which] takes the hard edges off things. Objects and ideas are fuzzy, misty."15

High-dissolution keeps us guessing and enables us to 'miss' Google Earth's objects and therefore incite our desire. The ostensibly trivial phenomenon of semi-naked people on Google Earth shows how Dionysian enjoyment resides not so much in the displayed objects themselves but rather in "ultimately the gaze itself" (Žižek, 1991, p. 91). Dionysus' eye or gaze (cf. Cosgrove, 2001) is neither a point of illusory mastery or deceptive transparency, nor does it emanate from or coincide with Google Earth users' eyes. Rather, the Dionysian eye (echoing a Benjaminian and Lacanian reading of the gaze) takes place where Apollonian mastery fails and "functions like a blot that blurs the transparency of the viewed image" (Žižek 1991, p. 114). In nuce, the Dionysian gaze is the fascination of not being able to clearly see the naked bodies.

To emphasize the precedence of the fascination of the gaze itself rather than the gazed at object, let us turn to the example of the US Holocaust Memorial Museum, which has joined Google in an unprecedented online mapping initiative called "Crisis in Darfur". This project, with its photographs, data, and eyewitness testimony,

"enables more than 200 million Google Earth users worldwide to visualize and better understand the genocide currently unfolding in Darfur, Sudan...Witness the destruction for yourself. Using coordinates provided by the United States Holocaust Memorial Museum, Google acquired high-resolution imagery over the region of Darfur and Eastern Chad. Now you can witness the destruction in Darfur via Google Earth. Zoom down and see what a burned village looks like from above, the vast tent cities of people displaced from their homes, and photographs on the ground of refugees struggling to survive. Read eyewitness testimony of atrocities in attacked villages. Visualize what genocide looks like today in Darfur."16

What are we to make of the Museum's initiative? On the one hand, we could affirm the project because of its aims to educate a broad audience about the geographical context of the crisis. On the other hand, we could decry the project's complicity in "disaster pornography" (Burman, 1994) to the extent that its mode of educating is fraught with the voyeuristic pleasure of examining yet more disasters, terrors, and destruction in Africa or other parts of the Global South. We are sympathetic to both of these readings but are weary of how they fall in line with Apollonian either/or logic. Instead, we prefer to evaluate this Google Earth project by turning to the Dionsyian infestation of a discussion incited by blogging war correspondent David Axe who, while using Google Earth, discovered crashed transport planes that fuelled speculation about US and UN allegations of gunrunning in Darfur (Fig. 5). ${ }^{17}$ The following is a transcript of several Google Earth users' attempts to make sense of Axe's Google Earth discovery:

\footnotetext{
15 Similarly, John Pickles (2004, p. 189) notes that the (re)codings of cartography by "institutionalized power" takes place "but always with leakage". Our paper responds to Pickles' injunction to "Go on, Go on!" by addressing without mopping up these leakages.

${ }^{16}$ See http://www.ushmm.org/googleearth/.

17 See http://www.theregister.co.uk/2007/05/30/darfur_gunrunner_on_google_ earth/.
} 

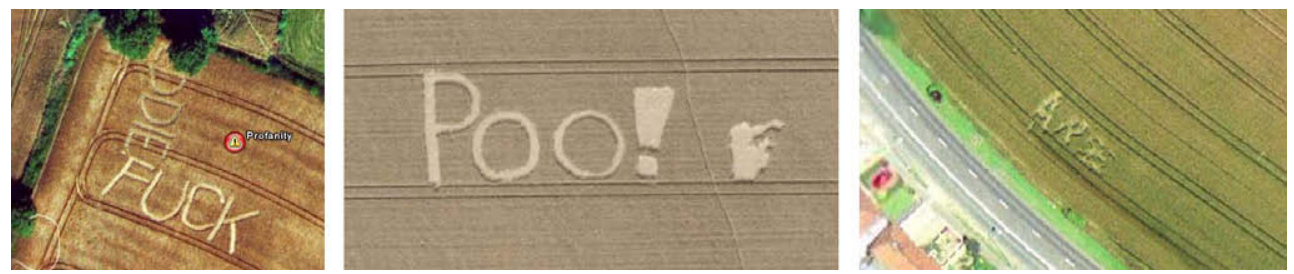

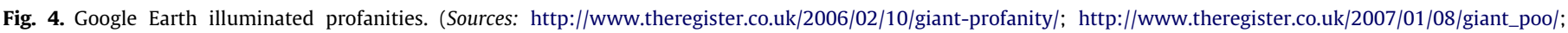

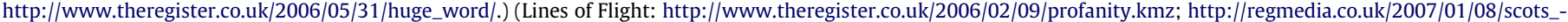
say_poo.kmz; http://regmedia.co.uk/2006/05/31/huge_arse.kmz).

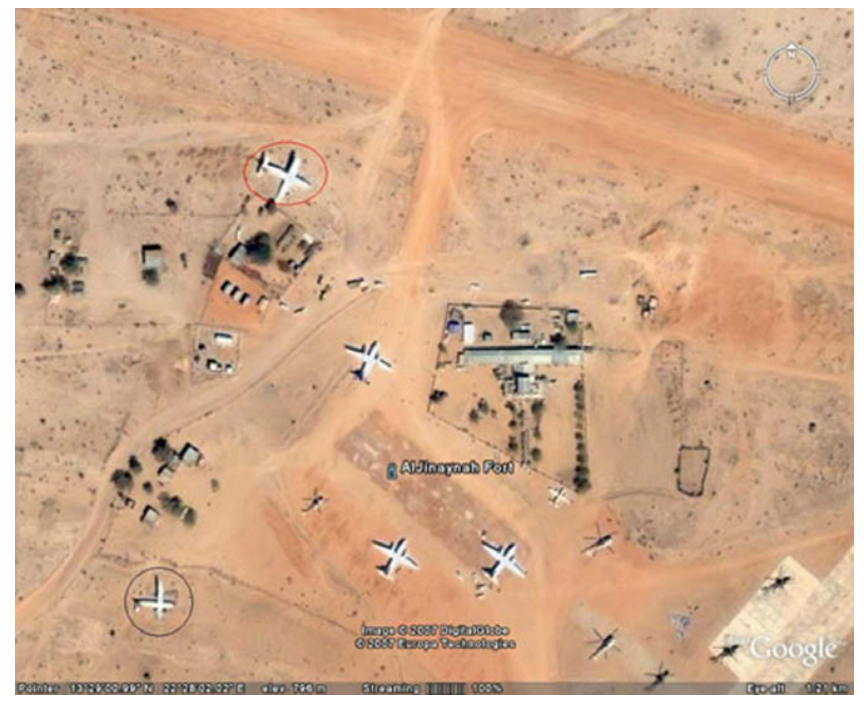

Fig. 5. Google Earth shot of Geneina Airport, Darfur. The damaged planes are circled. (Source: http://www.theregister.co.uk/2007/05/30/darfur_gunrunner_on_ google_earth/). (Line of Flight: http://regmedia.co.uk/2007/05/30/geneina_airport. $\mathrm{kmz})$.

"The UN photo shows the left wing grounded and the right wing up in the air. The red circled plane has its right wing grounded whereas the black circled plane has its left wing grounded. Does this not suggest the black circled one is the more likely of the two to be a match?"

"If you look at which wing is damaged, it appears to be the left. Of the two planes in the google image, it is the red one with left wing damage. The other appears to be missing most of its right wing."

"the black circled seems to have the right wing damaged. whereas the red circled and UN photo both have the left damaged."

"According to various sources (including Wikipedia, which is fab for this sort of trivia), an AN-12 is $\sim 33 \mathrm{~m}$ long. Using Google Earth's ruler, the top (circled in red) is $\sim 30 \mathrm{~m}$ long, and the bottom (in black) $\sim 20 \mathrm{~m}$, so I'd go with the top one. Mind, it's also possible that the plane in question isn't in this picture..."

“...the black one doesn't have anything left of it's [sic] rear wings, on the tail, whereas the one in the witness photo does, as does the red one on Google Earth."

"According to Google Earth's 'coverage' layer, the newest photos of that area are from mid-2006. Assuming that data is kept current anyway..."

What is so telling about the exchange above is how the search and compulsion to find the lurking meaning of the planes is fostered by the Apollonian tools of measuring (length and time), observing, and verifying. In this way, the Dionysian paranoiac gaze involves an "oscillation between lack and surplus meaning that constitutes the proper dimension of subjectivity" (Žižek 1991, p. 91). Thus the Dionysian forecloses the possibility of any neutral or impartial point of view in Google Earth because it hooks users into the image - "in a way, it is the point from which the picture looks back at us" (Žižek 1991, p. 91; or, in Benjamin's terms, 'returns our gaze'). Google Earth's profane illuminations, wherein objects gaze back at us as we disappear (see Doel, 2006) or get lost in meanings that are at once excessive and insufficient, demands attending to new geometries of power in scopic regimes.

\subsection{Discipline and anguish}

According to some conspiracy theorists, the phenomenon of unmarked black helicopters evince the imminent control of the world (especially the United States) by groups such as the New World Order (a secret autonomous world government), the Men in Black (shadowy quasi alien government agents), and the United Nations. For Google Earth users, black helicopters have become a useful resource for games and competitions such as 'Spot the Black Helicopter.' ${ }^{18}$ The proliferation of Google Earth users' images of black helicopters, black helicopter factories, and black helicopter hideouts evinces how Google Earth is not simply an online ideological state apparatus that reinforces hegemonic cartographic power.

Not that Google Earth is a-geopolitical. For example, in April 2007, the Government of Chile filed a complaint to Google Earth to re-draw a boundary around the border village Villa O'Higgins, which, despite being named after the Chilean independence hero, was found on Google Earth to reside in Argentine territory. ${ }^{19}$ Elsewhere, one Google Earth user discovered in Udorn Air Force base, located in Thailand, evidence of fighter jets made of "Top-quality, US-bought hardware". ${ }^{20}$ The user alleged that "[t]hey've even got an awacs parked there on the hard shoulder". Hence the parallel between Google Earth's Dionysian eye and what Gearóid ó Tuathail (1996, p. 173) calls the "anti-geopolitical eye": "an eye that disturbs and disrupts the hegemonic foreign policy gaze, a way of seeing that, while hardly unproblematic itself, persistently transgresses, unravels and exceeds". Ó Tuathail draws on the writings British journalist Maggie O'Kane whose dispatches disturbed the usual enframing of Bosnian Western geopolitical discourse as something located beyond the realm of moral responsibility.

But there is equally something quite Apollonian about working within the binaries of domination and resistance, conformity and transgression, fixity and flow, and death and life. For the Apollonian includes both the dialectic between dread and possibility, fear and hope, surveillance and resistance, power and its other, progressive critique and progressive action. Overall, the Apollonian involves a politics with a manufactured subjectivity: because you are

\footnotetext{
18 See http://www.theregister.co.uk/2005/10/14/google_earth_competition_results/. 19 See http://www.reuters.com/article/internetNews/idUSN2834134620070428? feedType=RSS.

${ }^{20}$ See http://www.theregister.co.uk/2005/09/13/google_earth_threatens_democracy/.
} 
a progressive academic and/or activist, you must resist, but precisely because you are that type of subject your choices will be limited to either optimism or pessimism. This rendering of the political is Apollonian to the core because it is sober, rational, calculated, and sincere. In contrast, the Dionysian involves a politics that is in use, immanent to the sites of practice such as interfacing with the computer screen (i.e., not scaled or made 'political' in advance), and assumption-less about the type of user or her subject position; nor is she necessarily sober, rational, or sensible. The Dionysian is a politics of the artist, anarchist, hacker - a position that might seem 'apolitical' at first glance, at least from the Apollonian elevated point of view. Even the sympathetic might see it as 'wasted' or 'for nothing'. But the Dionysian is also the place where new ways of political and ethical thinking emerge and where new epistemes are concocted and erupt.

Obviously, there are numerous instances where Google Earth is used in the service of Apollonian security and sobriety. For example, the sheriff's department of Humboldt County, California (one of the largest marijuana-growing regions in North America), has used GPS devices and Google Earth as "one piece in its marijuana interdiction activities". ${ }^{21}$ Also in the US, Google Earth has been used in tax assessments where at least one taxpayer has been ordered to pay fines for not reporting the building of new structures on land. ${ }^{22}$ And, it is increasingly integrated with geo-spatial video surveillance systems, such as GView ${ }^{\mathrm{TM}}$, the:

"first automated, intelligent video surveillance system using Google Earth ${ }^{\mathrm{TM}}$. GView ${ }^{\mathrm{TM}}$ incorporates patent pending technology that converts a facility's digital video recording (DVR) security system into 3D situation awareness system for rapid threat detection and assessment. As DVR manages and records video captured by a facility's cameras, GView ${ }^{\mathrm{TM}}$ simultaneously captures and processes the video and automatically detects and tracks the movements of all intruders (e.g. people, vehicles, and boats). When it detects a security breach, GView ${ }^{\mathrm{TM}}$ generates both a real time video of all intruders plus their movements on a 3D Google Earth ${ }^{\mathrm{TM}}$ display... GView's underlying intelligent video surveillance system is GuardianWATCH. It is a robust signal processing architecture that controls all cameras and non-video sensors, defines, prioritizes, detects and tracks threats, and monitors and controls available communication bandwidth." ${ }^{23}$

But sensing, defining, prioritizing, detection, tracking, and monitoring do not necessarily lead to more control. For all of these Apollonian elements can topologically flip over into Dionysian confusion and anxiety (see Kingsbury, 2007). Our claim here is that Google Earth can become a reversal of Bentham's panopticon (see Doel and Clarke, 1999; see also Gray, 2003; Hopkins, 2000; Koskela, 2003). On Google Earth, instead of the prisoners feeling anxious because they are not sure when they are being observed by the guards in the main control tower, it is also possible for the guards to feel anxious because they cannot see the prisoners. Often it is the Google Earth user (as well as the millions of people checking via the refresh button, for example, emails, breaking news stories, live-text sports commentaries) in the thrall of "cartophilias and cartoneuroses" (Painter, 2006) and at "the center of the Panopticon, its all-pervasive eye, who is terrorized, constantly looking out the window, anxious not to miss some crucial detail" (Žižek 1991, p. 92). For example, there was recently a heated online discussion about an object spotted by Paul Van Den Steene of Brussels that resembled a long range weapon of mass destruction found

\footnotetext{
21 See http://www.news.com/How+law+enforcement+uses+Google+Earth/21001025_3-6208034.html.

${ }^{22}$ See http://www.gearthblog.com/blog/archives/2005/12/tax_assessors_u.html.

23 See http://www.guardiansolutions.com/Products/threatstalker.asp.
}

near the runway of Luton Airport in England. It was eventually discovered that this 'missile' was actually a mock up of a Boeing 767 aircraft fuselage used for fire and rescue training exercises. ${ }^{24}$ There was also the strange sighting of a World War II allied bomber, anachronistically but nonetheless menacingly flying over Stukeley Meadows, Huntingdon, England. ${ }^{25}$ After months of heated debate it was discovered that the object was an 'Avro Lancaster', flying about as part of the Battle of Britain Memorial Flight's 'City of Lincoln'. In addition to all of the profanity, jouissance (enjoyment) (see Copjec, 1994; Mulvey, 1989), and anxiety caused by Google Earth, it also generates mysteries that resist interpretation, many of which echo Benjamin's preoccupation with the technique of photomontage and what the surrealist André Breton called frottage - "intensifying the irritability of the mind's faculties" (Shapazian, 1992, p. 161). And so it is to a brief discussion of the aesthetics and enigmas of Google Earth that we now turn.

\subsection{The mysterious art of Google Earth}

The Dionysian methods of montage and frottage that disrupt Apollonian tight-knit and predictable boundaries are expressed in these strange Google Earth tracts of the city of Edmonton in Alberta, Canada that enjoy simultaneously summer and winter (Fig. 6). ${ }^{26}$ As one Google Earth user notes:

"Scientists reckon global warming has resulted in our weather becoming increasingly unpredictable, and nowhere is this better demonstrated than in Canada's Edmonton, where locals venturing outside have to decide whether to slip on a pair of Bermudas and slap on the suntan lotion, or deploy the puffa jacket and snow boots."

We find these images interesting not simply because of their zany bi-seasonal disorder but also because of their aura, their "poetics of space" (Bachelard, 1994): the cold cracked tarmac that fades into the sun dried side of the bridge - a bridge that splits the North Saskatchewan River into ice on the one side and warm green water on the other. We also enjoy the long winter shadows of the houses and trees that stretch across the gardens and paths next to the lush summer foliage. In short, we love the colors and sensations that bloom between and beyond these pictures and us. We would even venture to say that the images' singularities are comparable to Cézanne's painting, 'Montagne Sanite Victoire', which for Lyotard (1988, p. 19) showed "how irrelevant for painting pictures are such values as meaning, consistency, likelihood, recognition, identification - one's only concern is to glance at the birth of colors, like the dawn of a cloud on the horizon." Google Earth's ability to conjure a wide pixel palette of alluring colors, images, and shapes is certainly one of the reasons why it has now become part of the burgeoning genre of aerial landscape art. ${ }^{27}$ For example, this image (Fig. 7), simply entitled, 'Google Earth art', by Drew 'DrGlass' Hornbein, is in Benjaminian fashion a montage of images of Chicago, New York, Detroit, Shanghai, Hong Kong, Berlin, Iraq [sic], Kuwait [sic], Atlanta, and Los Angeles, ${ }^{28}$ giving us not only juxtapositions of vaguely familiar objects but also a fantastical expression of color and casting of shapes. Dwelling briefly on the sublime beauty of Google Earth - as a large dose of the Dionysian and a pinch of the Apollonian - reveals it to be more than a socio-political product

\footnotetext{
$\overline{24}$ See http://www.theregister.co.uk/2006/01/18/google_challenge_result/ page3.html.

${ }^{25}$ See http://www.theregister.co.uk/2006/01/09/google_lancaster/.

26 See http://www.theregister.co.uk/2006/08/25/google_earth_two_seasons/.

27 See http://earthasart.gsfc.nasa.gov/index.htm which shows images taken by the Landsat-7 satellite and the Terra Satellite's Advanced Spaceborne Thermal Emission and Reflection Radiometer.

${ }^{28}$ See http://drglass.deviantart.com/art/Google-earth-art-32453380.
} 

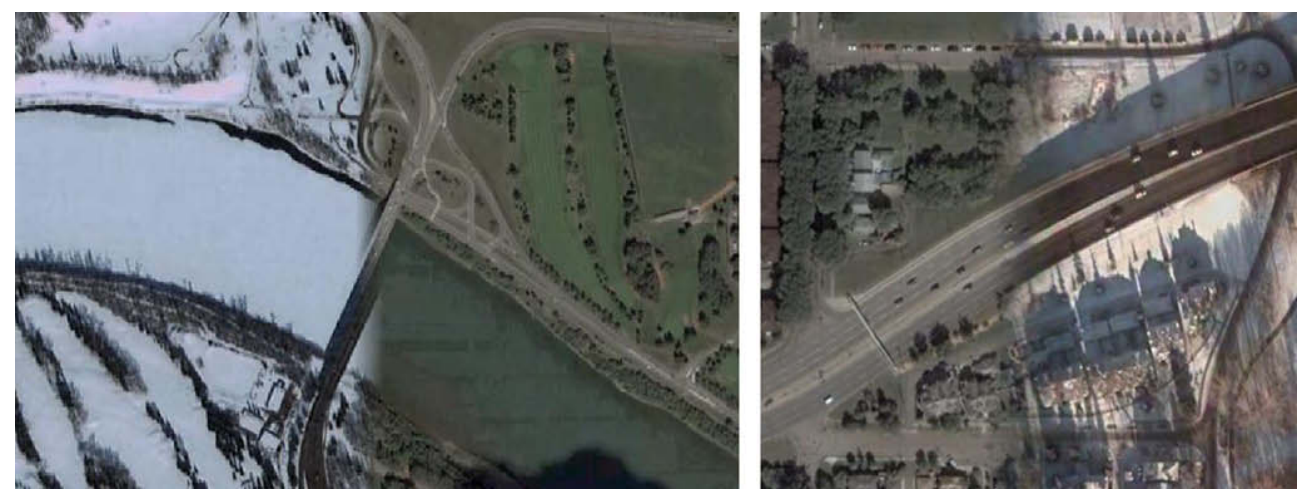

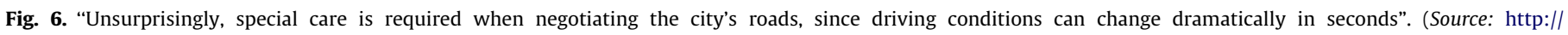
www.theregister.co.uk/2006/08/25/google_earth_two_seasons/).

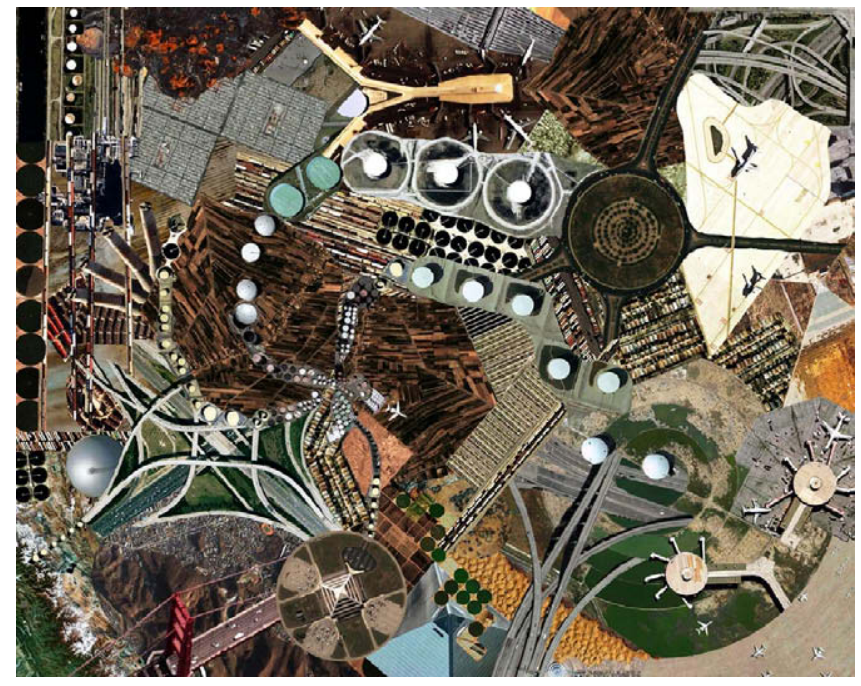

Fig. 7. Google Earth art by Dr. Glass. Reproduced with kind permission of Drew Hornbein. (Source: http://drglass.deviantart.com/art/Google-earth-art-32453380).

demanding sophisticated, major theories. As Tim Dean (2002, p. 21) notes:

"Today it is normative to read literature, film, and other cultural texts primarily as evidence about the societies that made them - evidence that necessarily requires our hermeneutic labor in order to yield its significance. This methodological protocol remains in place whether one inhabits critical perspectives as ostensibly disparate as historicist, materialist, or psychoanalytic modes of thinking; it is also a grounding assumption of cultural studies, irrespective of how one defines that critical practice." (Dean, 2002, p. 21)

We agree with Dean's assertion that it is important to analyze the obdurate mystery of cultural and aesthetic artifacts, that is, to bring out elements that resist interpretation or the predictable operations of ideological unveiling or deconstructive dissemination (see also Kingsbury, 2009). Dean's critique is primarily aimed at the ravenous interpretations of Žižek, which politicize psychoanalysis at the expense of what Dean calls an “ethical psychoanalysis.” Dean's favored approach to art is via Jean Laplanche's Lacanian notion of the 'enigmatic signifier' which, he argues, can respect the otherness of art. As Dean (2002, p. 38) notes:
"While we try to respect the otherness of other persons, our interpretive practices do not respect the otherness of art. It is as if art needed to come from an alien culture before we could concede that some aspect of it remains untranslatable into meaning."

In this regard, we affirm the capacity of Google Earth to convey some of the aesthetic qualities comparable to those J. Brian Harley found in maps. In discussing Sheet CIX, SE - his "favourite map" that depicts his former home in a small Devon town in England Harley reflects on how the map "ceases to be a document of social relevance or the utilitarian product of government policy: it is there to be read as a personal history, an affirmation that I still belong" (1987, p. 20) emphasis added). Google Earth affirms our senses of belonging and our longing to belong. While such pursuits may rely heavily on acts of distanced looking, it is Google Earth's 'ways of seeing' that are liable to and in many cases fuelled by the rattle and hum of Dionysian energies. For who amongst us has not flown on the magic carpet of Google Earth and gotten a kick out of and also felt a certain sadness while flying over the many places of our forever former lives, and those of our families, friends, and lovers?

Benjamin was no stranger to thinking about and submitting to these intensities of joy and melancholy when looking at images. One of his prized possessions was Paul Klee's painting, Angelus Novus (Fig. 8). The painting, which fascinated and horrified Benjamin (1969b, p. 257-258),

\begin{abstract}
"shows an angel looking as though he is about to move away from something he is fixedly contemplating. His eyes are staring, his mouth is open, his wings are spread. This is how one pictures the angel of history. His face is turned toward the past. Where we perceive a chain of events, he sees one single catastrophe which keeps piling wreckage upon wreckage and hurls it in front of his feet. The angel would like to stay, awaken the dead, and make whole what has been smashed. But a storm is blowing from Paradise; it has got caught in his wings with such violence that the angel can no longer close them. This storm irresistibly propels him into the future to which his back is turned, while the pile of debris before him grows skyward. The storm is what we call progress."
\end{abstract}

And perhaps too there is an angel of geography, encountered this time on Google Earth (Fig. 9)? The image shows a strange face (Berkner Island, the southern-most island in the world) as part of Western Antarctica's frozen landscape, on the coast of the Weddell Sea. Like Benjamin's angel of history, the face stares with mouth open wide, perhaps turned toward a recent past where it also perceives a chain of events and one potential catastrophe: the ecolog- 


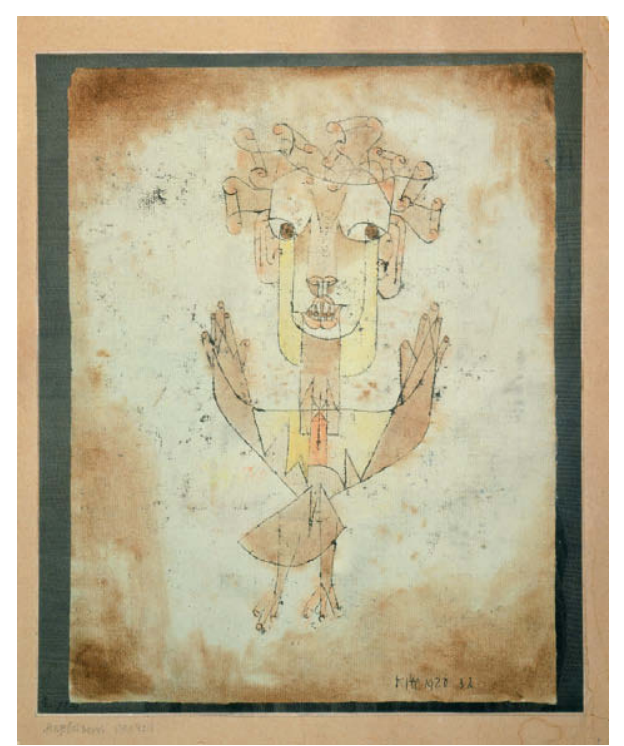

Fig. 8. Angelus Novus (1920) by Paul Klee. India ink, color chalks, and brown wash on paper. (Source: Reproduced with kind permission of The Israel Museum, Jerusalem. (C) Estate of Paul Klee/SODRAC).

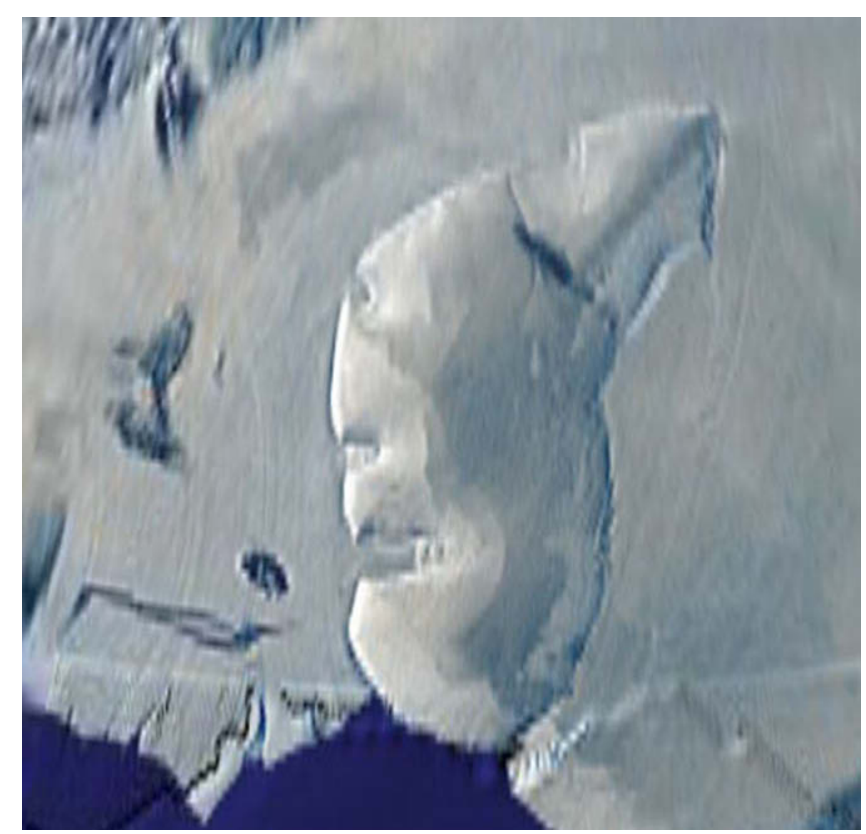

Fig. 9. An angel of geography? (Source: http://www.theregister.co.uk/2005/10/14/ google_earth_competition_results/page5.html).

ical destruction of Planet Earth. How so? We wonder if the face, partly an exposure of snow and ice, is the result of one of the storms of progress we call global warming. And how will the face metamorphose in the future? Will it melt and disintegrate, only to be washed over with newly-formed debris resulting from rising sea levels? We do not know the answer to these questions, but amidst these speculations on Google Earth, we take heart in Oscar Wilde's (2000, p. 24) reminder that it is "only shallow people who do not judge by appearances. The true mystery of the world is the visible, not the invisible".

\section{Conclusion}

This paper began as an effort to re-think the available political positions existing within critical approaches to GSTs. These have been usefully summarized in critical cartography by Crampton and Krygier (2006) as a "one-two punch" (also, Harris and Weiner, 1998). On the one hand are critiques of mainstream cartography, a tradition that is still aptly summarized by the dystopic view of mapping taken over 30 years ago by the French Marxist, Yves Lacoste:

"The map, perhaps the central referent of geography, is, and has been, fundamentally an instrument of power. A map is an abstraction from concrete reality which was designed and motivated by practical (political and military) concerns; it is a way of representing space which facilitates its domination and control. To map...serves the practical interests of the State machine." (Lacoste, 1973, quoted in Crampton and Krygier, 2006, p. 21-22).

Lacoste's writing has since been complemented by a wide range of critical approaches stressing the role of GSTs in a space/power nexus characterized by state organized militarization, capitalistled rationalization, and technology enhanced ocularcentrism, all hand-in-hand with receding rights of privacy (Harris, 2006). By now most geographers are familiar with the names that have come to work in one way or another from these perspectives, including the key works by Denis Wood (Wood and Fels, 1986; Wood 1992), Harley (1988, 1989), Smith (1992), Goss (1995), Pickles (1995), and Curry (1997), among others.

These critical perspectives have been joined, on the other hand, by an impressive set of work arguing for the deployment of GSTs, whether on behalf of, or in the hands of, marginalized peoples. Given that geo-technologies, especially GIS, can be empowering in certain contexts (Ghose and Elwood, 2003), a new generation of techno-savvy scholars now advocate the use of advanced technologies to map communities and confront state and capitalist hegemonies (Craig et al., 2002; Sheppard, 1995; Sieber, 2006). As Crampton and Krygier (2006, p. 12) summarize this situation:

"One might expect a critique of the politics of mapping to weaken the power of the map and to work against a transition putting maps into more people's hands. But just the opposite has happened. If the map is a specific set of power-knowledge claims, then not only the state but others could make competing and equally powerful claims."

All of this has led to what Nadine Schuurman (2000) identified as a late 1990s rapprochement between GIS scholars and their critics (see also O'Sullivan, 2006). Added to this equation is a range of new mapping practices: alternative cartographies that have a history in the surrealism and Dadaism of the early 20th century (Wood, 2007), and which today find adherents in the hands of artists and activists, including some who are producing subversive, 'people's cartographies' (Cieri, 2007; kanarinka, 2006, 2007) that parallel developments in GISoc, PPGIS, and PGIS.

What has remained in place, however, is a domination-resistance dialectic that is capable of encircling Google Earth and bringing it into the Apollonian fold. Here we aimed to augment this perspective - to keep Google Earth spinning, so to speak through Benjamin's Dionysian approach. We pointed to his alternative affirmations: the giddiness of childhood, the enchantments of surrealism, the pleasures in wandering, the dislocations of montage, and the virtualities released by intoxication. ${ }^{29}$ With all these things in play, it is perhaps no wonder that Google Earth has a website devoted to addiction. As Jeff Keegan, writing on his

\footnotetext{
${ }^{29}$ And to be sure, there are cartographers whose work is moving in this direction. Recently for example, Chris Perkins (2006) has encouraged geographers to 'play' with maps for personal pleasure, while Denis Wood and John Krygier are building a large project around maps and art (Wood and Krygier, 2007; Krygier, 2007).
} 
'Google Earth Addiction' website, warns: "When I was introduced to Google Earth, I was told it would rob me of about 40 days of my life. That was clearly an optimistic prediction - I'm waaaay past that." 30

\section{Acknowledgements}

Many thanks to audiences at Arizona State University and Indiana University for comments, as well as to attendees at the 2007 Association of American Geographers meeting, the 2007 Association of Pacific Coast Geographers meeting, and the 14th Annual Conference on Critical Geography. The comments of Martin Dodge, Nick Hedley, Dan Knudsen, Sarah de Leeuw, Jeff Garmany, Caren Kaplan, Chris Lukinbeal, Vanessa Massaro, Kevin McHugh, Chris Perkins, Ian Shaw, Matt Sparke, Joel Wainwright, Scott Whitlock, and Denis Wood are especially appreciated.

\section{References}

Adorno, T.W., 1967. Prisms. The MIT Press, Cambridge, MA.

Adorno, T.W., 1981/82. Transparencies on film. New German Critique (24/25), 199205.

Adorno, T.W., 1989. The culture industry reconsidered. In: Bronner, S.E., Kellner, D.M. (Eds.), Critical Theory and Society: A Reader. Routledge, New York, pp. $128-135$.

Adorno, T.W., 1990. The curves of the needle October 55 (Winter), 48-55.

Adorno, T.W., 2005. Minima Moralia: Reflections on a Damaged Life. Verso, New York.

Bachelard, G., 1994. The Poetics of Space. Beacon Press, Boston.

Benjamin, W., 1969a. The work of art in the age of mechanical reproduction. In: Arendt, H. (Ed.), Illuminations. Schocken Books, New York, pp. 217-251.

Benjamin, W., 1969b. Theses on the philosophy of history. In: Arendt, H. (Ed.) Illuminations. Schocken Books, New York, pp. 253-264.

Benjamin, W., 1978. Surrealism: the last snapshot of the European intelligentsia New Left Review 108 (March-April), 47-56.

Benjamin, W., 1999. The Arcades Project. In: Eiland, H., McGlaughlin, K. (Trans.). Harvard University Press, Cambridge.

Benjamin, W., 2006. On Hashish. Harvard University Press, Cambridge, MA.

Benjamin, W., Adorno, T.W., 2003. The Complete Correspondence. Blackwell, New York.

Benjamin, W., Lacis, A., 1978. Naples. In: Demetz, P. (Ed.), Reflections. Schocken Books, New York, pp. 163-173.

Buci-Glucksmann, C., 1994. Baroque Reason: The Aesthetics of Modernity. Sage, Thousand Oaks, CA.

Burman, E., 1994. Innocents abroad: western fantasies of childhood and the iconography of disasters. Disasters 18 (3), 238-253.

Caplan, K., 2006. Precision targets: GPS and the militarization of US consumer identity. American Quarterly 58 (3), 693-713.

Castle, T., 1988. 'Phantasmagoria': spectral technology and the metaphorics of modern reverie. Critical Inquiry 15 (1), 26-61.

Cieri, M., 2007. Mapping 'irresolvable geographies'. In: Paper Presented the Conference, 'Geography and the Humanities Symposium', June 22-24, Charlottesville, VA.

Copjec, J., 1994. Read My Desire: Lacan Against the Historicists. The MIT Press, Cambridge, MA.

Cosgrove, D., 1994. Contested global visions: One-World, Whole-Earth, and the Apollo space photographs. Annals of the Association of American Geographers 84 (2), 270-294.

Cosgrove, D., 2001. Apollo's Eye: A Cartographic Genealogy of the Earth in the Western Imagination. Johns Hopkins University Press, Baltimore.

Craig, W., Harris, T., Weiner, D. (Eds.), 2002. Community Participation and Geographic Information Systems. Routledge, London.

Crampton, J.W., Krygier, J., 2006. An introduction to critical cartography. ACME: An International E-Journal for Critical Geographies 4 (1), 11-33.

Curry, M., 1997. The digital individual and the private realm. Annals of the Association of American Geographers 87 (4), 681-699.

Dean, T., 2002. Art as symptom: Žižek and the ethics of psychoanalytic criticism. Diacritics 32 (2), 21-41.

Doel, M.A., 2006. The obscenity of mapping. Area 38 (3), 343-345.

Doel, M.A., Clarke, D.B., 1999. Dark panopticon. Or, attack of the killer tomatoes. Environment and Planning D: Society and Space 17 (4), 427-450.

Doel, M.A., Clarke, D.B., 2007. Afterimages. Environment and Planning D: Society and Space 25 (5), 890-910.

Elwood, S., 2006. Beyond cooptation or resistance: urban spatial politics, community organizations, and GIS-based spatial narratives. Annals of the Association of American Geographers 96 (2), 323-341.

Freud, S., 1961. Civilization and its Discontents. Norton, New York.

30 See http://www.keegan.org/jeff/googleearth/index.html.
Ghose, R., Elwood, S., 2003. Public participation GIS and local political context: propositions and research directions. URISA Journal 15 (4), 17-24.

Goodchild, M., 2007. Citizens as sensors: the world of volunteered geography. Geojournal 69 (4), 211-221.

Goss, J., 1995. 'We know who you are and we know where you live': the instrumental rationality of geodemographic systems. Economic Geography 71 (2), 171-199.

Gray, M., 2003. Urban surveillance and panopticism: will we recognize the facial recognition society? Surveillance and Society 1 (3), 314-330.

Hansen, M.B., 1981/82. Introduction to Adorno, "transparencies on film (1966)". New German Critique (24/25), 186-198.

Haraway, D.J., 1988. Situated knowledges: the science question in feminism and the privilege of partial perspective. Feminist Studies 14 (3), 575-599.

Harley, B., 1987. My favourite map. Map Collector 41, 20.

Harley, B., 1989. Deconstructing the map. Cartographica 26 (2), 1-20.

Harley, B., 1988. Secrecy and silences: the hidden agenda of state cartography in early modern Europe. Imago Mundi 40, 57-76.

Harris, C., 2006. The omniscient eye: satellite imagery, 'battleship awareness', and the structures of the imperial gaze. Surveillance and Society $4(1 / 2), 101-$ 122.

Harris, T., Weiner, D., 1998. Empowerment, marginalization and 'communityintegrated' GIS. Cartography and Geographic Information Systems 25 (2), 6776.

Hedley, N., 2009. Real-time reification: how mobile augmented reality may define our relationship with geographic space. In: Badard, T., Daniel, S. (Eds.), Mobile Geospatial Augmented Reality. Springer, New York.

Hoeschele, W., 2000. Geographic information engineering and social ground truth in Attappadi, Kerala State, India. Annals of the Association of American Geographers 90 (2), 293-321.

Hopkins, J., 2000. Signs of Masculinism in an 'uneasy' place: advertising for 'Big Brothers'. Gender, Place and Culture 7 (1), 31-55.

Horkheimer, M., Adorno, T.W., 1991. Dialectic of Enlightenment. Continuum, New York.

Jay, M., 1984. Marxism and Totality: the Adventures of a Concept from Lukács to Habermas. University of California Press, Berkeley.

kanarinka, 2006. Designing for the totally inconceivable: mods, hacks and other unexpected uses of maps by artists (and other regular people). In: Paper Presented at the Annual Meeting of the Association of American Geographers, March 7-11, Chicago, IL.

kanarinka, 2007. The city formerly known as Cambridge. In: Paper Presented at the Conference, 'Geography and the Humanities Symposium', June 22-24, Charlottesville, VA.

Katz, C., 1996. Towards minor theory. Environment and Planning D: Society and Space 14 (4), 487-499.

Kellner, D., 1989. Critical Theory, Marxism and Modernity. Johns Hopkins University Press, Baltimore.

Kingsbury, P., 2007. The extimacy of space. Social and Cultural Geography 8 (2), 235-258.

Kingsbury, P., 2009. Unearthing Nietzsche's bomb: explosiveness, nuance, aesthetics. ACME: An International E-Journal for Critical Geographies.

Kitchin, R., Dodge, M., 2007. Rethinking maps. Progress in Human Geography 31 (3), 331-344.

Klinkenberg, B., 2007. Geospatial technologies and the geographies of hope and fear. Annals of the Association of American Geographers 97 (2), 35-360.

Koskela, H., 2003. "Cam Era”: the contemporary urban panopticon. Surveillance and Society 1 (3), 292-313.

Krygier, J., 2007. UnMaking maps. In: Paper Presented at the Conference, 'Geography and the Humanities Symposium', June 22-24, Charlottesville, VA.

Lammeren, R.J.Van, Bergsma, A.R., 2006. Towards Geodata-based Communities: moving from mapping tool to digital peep-box. GIM International 20 (8), 3133.

Leary, T., 1994. Chaos and Cyber Culture. Ronin, Berkeley.

Lefebvre, H., 1991. The Production of Space. Blackwell, Oxford.

Lykke, N., Braidotti, R. (Eds.), 1996. Between Monsters, Goddesses and Cyborgs: Feminist Confrontations with Science, Medicine and Cyberspace. Zed Books, London.

Lucas, R., 2004. Inscribing the city: a flâneur in Tokyo. Anthropology Matters Journal $6(1), 1-11$.

Lyotard, J., 1988. Peregrinations: Law, Form, Event. Columbia University Press, New York.

Matless, D., 1992. Regional surveys and local knowledges: the geographical imagination in Britain, 1918-39. Transactions of the Institute of British Geographers 17 (4), 464-480.

Mulvey, L., 1989. Visual and Other Pleasures. Palgrave, New York.

Nietzsche, F., 1999. The Birth of Tragedy and Other Writings. Cambridge University Press, Cambridge, MA.

O'Sullivan, D., 2006. Geographical information science: critical GIS. Progress in Human Geography 30 (6), 783-791.

Ó Tuathail, G., 1996. An anti-geopolitical eye: Maggie O’ Kane in Bosnia, 1992-93. Gender, Place and Culture 3 (2), 171-185.

Paglia, C., 1991. Sexual Personae: Art and Decadence from Nefertiti to Emily Dickinson. Vintage, New York.

Paglia, C., 1994. Vamps and Tramps: New Essays. Vintage, New York.

Painter, J., 2006. Cartophilias and cartoneuroses. Area 38 (3), 345-347.

Perkins, C., 2006. Playing with maps. In: Paper Presented at the Annual Meeting of the Association of American Geographers, March 7-11, Chicago, IL 
Philo, C., 2006. Geography in an age of unreason. In: Paper Presented at the Conference, 'Emotional Geographies, the Second International and Interdisciplinary Conference', May 25-27, Queen's University, Kingston, ON.

Pickles, J. (Ed.), 1995. Ground Truth: The Social Implications of Geographic Information Systems. The Guilford Press, New York.

Pickles, J., 2004. A History of Spaces: Cartographic Reason Mapping and the GeoCoded World. Routledge, New York.

Rose, G., 1993. Feminism and Geography: The Limits of Geographical Knowledge. Polity Press, Cambridge.

Schuurman, N., 2000. Trouble in the heartland: GIS and its critics in the 1990s. Progress in Human Geography 24 (4), 569-590.

Shapazian, R. (Ed.), 1992. The Surrealists Look at Art. Lapis Press, Venice, CA.

Sheppard, E., 1995. GIS and society: towards a research agenda. Cartography and Geographic Information Systems 22 (1), 5-16.

Sieber, R., 2006. Public participation geographic information systems: a literature review and framework. Annals of the Association of American Geographers 96 (3), 491-507.

Smith, N., 1992. History and philosophy of geography: real wars, theory wars. Progress in Human Geography 16, 257-271.

Sontag, S., 2002. Under the Sign of Saturn. Picador, New York.
Sparke, M., 2008. Political geography - political geographies of globalization III: resistance. Progress in Human Geography 32 (3), 423-440.

Turnbull, A., Turnbull, J., 2006. Off the Map: The Most Amazing Sights on Earth as Seen by Satellite. Springer, Berlin.

Wainwright, J., 2009. Nietzsche contra the real world. ACME: An International EJournal for Critical Geographies.

Wilde, O., 2000. The Picture of Dorian Gray. Penguin, London.

Wolin, R., 2006. The Frankfurt School Revisited and Other Essays on Politics and Society. Routledge, New York.

Wood, D., 1992. The Power of Maps. The Guilford Press, New York.

Wood, D., 2007. Maps and map art. In: Paper Presented at the Conference, 'Geography and the Humanities Symposium', June 22-24, Charlottesville, VA.

Wood, D., Fels, J., 1986. Designs on signs: myth and meaning in maps. Cartographica 23 (3), 54-103.

Wood, D., Krygier, J., 2007. C'est ne pas le monde. In: Paper Presented at the Conference, 'Geography and the Humanities Symposium', June 22-24, Charlottesville, VA.

Žižek, S., 1991. Looking Awry: An Introduction to Jacques Lacan Through Popular Culture. The MIT Press, Cambridge, MA

Zook, M., Graham, M., 2007. The creative reconstruction of the Internet: Google and the privatization of cyberspace and DigiPlace. Geoforum 38 (6), 1322-1343. 